\title{
PENGARUH PENAMBAHAN EKSTRAK LIDAH BUAYA (Aloe vera) PADA PEMBUATAN KERUPUK
}

\author{
Effect Of Addition Of Extract Aloe Vera On Making Crackers \\ Qoidatul Sholiha $^{1)}$, Hapsari Titi Palupi ${ }^{1)}$ \\ ${ }^{1)}$ Prodi Ilmu dan Teknologi Pangan, Universitas Yudharta Pasuruan \\ Qaida.fania@gmail.com
}

\begin{abstract}
Crackers are dry food products that have been long known to the people of Indonesia. Crackers normally consumed as a snack or as a complement to the dish. Aloe vera (Aloe vera) be processed crackers is a form of work done in raising the value-added fiber and nutritional value of raw materials used in the production process. This study aims to determine the effect of the proportion of aloe vera extract and flour to the crackers quality aloe extract and determine the proportion of aloe vera extract and flour cracker to produce a quality aloe vera extract. This study uses a single randomized design (RAT) with 1 factor is the proportion of aloe vera and tapioca flour. This factor comprises five variables: $A 1=$ extract of aloe vera: tapioca (0: 100), A2 = extract of aloe vera: tapioca (10: 90), $A 3=$ extract of aloe vera: tapioca (20: 80), A4 = extract of aloe vera : tapioca (30: 70), $A 5=$ extract of aloe vera: tapioca (40: 60) the data obtained were analyzed by ANOVA and least significant difference test continued (BNT) 5\%. The best treatment at this empirically is the treatment of $A 4$ (aloe extract $30: 70$ tapioca) with the following characteristics: an average moisture content of 12.01\%; antioxidant 7.75\%; unfolding 67.84\%; Oil Adsorption 5.50\%; and the average A-level panelists to taste 4.40 (like); aroma 3.40 (neutral); and texture 3.90 (like).
\end{abstract}

Key words: aloe vera,extract, kerupuk, kerupuk process.

\begin{abstract}
ABSTRAK
Kerupuk merupakan produk makanan kering yang sudah lama dikenal masyarakat Indonesia. Kerupuk biasanya dikonsumsi sebagai makanan kecil atau sebagai pelengkap hidangan. Tanaman lidah buaya (Aloe vera) menjadi olahan kerupuk adalah suatu bentuk usaha yang dilakukan dalam meningkatkan nilai tambah dan nilai gizi serat dari bahan baku yang digunakan dalam proses produksi. Penelitian ini bertujuan untuk mengetahui pengaruh antara proporsi ekstrak lidah buaya dan tepung terhadap kualitas kerupuk ekstrak lidah buaya dan mengetahui proporsi ekstrak lidah buaya dan tepung untuk menghasilkan kerupuk ekstrak lidah buaya yang berkualitas. Penelitian ini menggunakan rancangan acak tunggal (RAT) dengan 1 faktor yaitu proporsi lidah buaya dan tepung tapioka. Faktor ini terdiri 5 variabel yaitu $\mathrm{A} 1=$ ekstrak lidah buaya : tapioka $(0: 100), \mathrm{A} 2=$ ekstrak lidah buaya : tapioka (10:90), A3 = ekstrak lidah buaya : tapioka (20:80), A4 = ekstrak lidah buaya : tapioka (30:70), A5 = ekstrak lidah buaya : tapioka (40:60) Data yang diperoleh dianalisis dengan uji sidik ragam dan dilanjutkan uji beda nyata terkecil (BNT) 5\%. Perlakuan terbaik pada penelitia ini adalah perlakuan A4 (ekstrak lidah buaya 30 : tapioka 70 ) dengan karakteristik sebagai berikut : rata-rata kadar air 12,01\%; antioksidan 7,75\%; daya kembang $67,84 \%$; daya serap minyak $5,50 \%$; serta rata-rata tingkat kesukaan panelis terhadap rasa 4,40 (menyukai); aroma 3,40 (netral); dan tekstur 3,90 (menyukai).
\end{abstract}

Kata kunci : lidah buaya, ekstrak, kerupuk, proses pengolahan kerupuk 


\section{PENDAHULUAN}

Kerupuk merupakan produk makanan kering yang sudah lama dikenal masyarakat Indonesia. Kerupuk biasanya dikonsumsi sebagai makanan kecil atau sebagai pelengkap hidangan pada saat makan. Menurut Rosiani (2011) hampir disemua lapisan masyarakat menggemari kerupuk, karena harganya terjangkau dan mudah diperoleh baik diwarung-warung kecil, supermarket, sampai hotel berbintang. Santoso (2008) menyatakan bahwa bahanbahan yang digunakan dalam proses pembuatan kerupuk meliputi bahan baku utama, dan bahan pembantu.

Lidah buaya merupakan komoditas pertanian yang memiliki peluang besar untuk dikembangkan dalam usaha agribisnis di Indonesia. Tanaman ini biasanya hanya dimanfaatkan sebagai obat penyubur rambut. Peningkatan ilmu pengetahuan dan teknologi mengakibatkan pemanfaatan lidah buaya semakin berkembang (Fitrina, 2012). Belakangan ini tanaman lidah buaya menjadi semakin populer karena manfaatnya yang semakin luas diketahui yakni sebagai sumber penghasil bahan baku untuk aneka produk dari industri makanan, farmasi, dan kosmetik (Purwaningsih, 2008).

Menurut Rosiani (2011) dalam penelitian tugas akhirnya, difersifikasi produk olahan daging lidah buaya masih sangat terbatas. Untuk itu perlu dikembangkan cara pengolahan pangan dari daging lidah buaya seperti pembuatan kerupuk dengan bahan baku tapioka yang kemudian difortifikasikan dengan daging lidah buaya.

Penelitian yang dilakukan adalah untuk mengetahui kandungan gizi dari kerupuk lidah buaya, dimana menurut Harper (1986) orang mengkonsumsi zat gizi yang terkandung dalam pangan untuk memberikan energi kepada tubuh, mengatur proses-proses tubuh. Tujuan penelitian adalah mengetahui konsentarasi ekstrak lidah buaya dan tapioka untuk menghasilkan kerupuk ekstrak lidah buaya yang berkualitas.

\section{BAHAN DAN METODE}

\section{Bahan dan Alat}

Bahan-bahan yang digunakan dalam penelitian adalah: lidah buaya, tepung tapioka, air, dan bumbu-bumbu (garam dan bawang putih). Alat-alat yang dipergunakan untuk penelitian adalah: kompor gas, dandang, pisau, stainlees steel, baskom, timbangan analitik, pencetakan dadar (teflon), nampan, saringan, gelas ukur, sendok, dan blender.

\section{Rancangan Percobaan}

Percobaan dilakukan dengan menggunakan rancangan acak tunggal (RAT) dengan 1 faktor yaitu proporsi lidah buaya dan tepung tapioka. Faktor ini terdiri 5 variabel dan masing-masing perlakuan diulang sebanyak 3 kali.

Secara lengkap perlakuan yang diberikan adalah sebagai berikut:

A1 $=$ ekstrak lidah buaya $:$ tapioka $(0: 100)$

A2 = ekstrak lidah buaya : tapioka $(10: 90)$

A3 = ekstrak lidah buaya : tapioka $(20: 80)$

A4 = ekstrak lidah buaya : tapioka $(30: 70)$

A5 $=$ ekstrak lidah buaya $:$ tapioka $(40: 60)$

\section{Ekstraksi Lidah Buaya}

Lidah Buaya dikupas, dipotong dan dicuci. Lidah buaya di blansir menggunakan air dengan suhu $90^{\circ} \mathrm{C}$ selama 15 menit. Selanjutnya dibentuk bubur dengan penghancuran menggunakan blender, disaring dan diperoleh ekstrak lidah buaya

\section{Pembuatan Kerupuk Lidah Buaya (cara basah)}

Adonan kerupuk dibuat dengan mencampurkan esktrak lidah buaya, tepung tapioka, Bawang putih halus, garam. Adonan diaduk dan selanjutnya dilakukan pencetakan dengan memakai teflon selama 15-20 detik suhu $100^{\circ} \mathrm{C}$. Pendinginan dari cetalakn sudah terbentuk. Tahap selanjutnya pengeringan dengan menggunakan panas matahari. Kerupuk lidah buaya siap digoreng. 


\section{Analisis Data}

Variabel pengamatan fisik kimia meliputi kadar air (oven), antioksidan (DPPH), daya kembang dan daya serap minyak. Dari data pengamatan sifat fisik, kimia dilakukan uji analisis ragam ANOVA $5 \%$ dan $1 \%$. Apabila ditemukan pengaruh terhadap salah satu variabel maka dilanjutkan dengan uji beda nyata terkecil (BNT). Untuk uji organoleptik menggunakan uji Friedman pada $5 \%$.

\section{Pengamatan}

Pengamatan yang dilakukan pada kerupuk ekstrak lidah buaya dilakukan analisa kimia yang meliputi kadar air dan antioksidan, analisa fisik meliputi daya kembang dan daya serap minyak, dan analisa organoleptik meliputi kesukaan terhadap rasa, aroma dan tekstur (kerenyahan).

\section{Analisa data}

Analisis ragam dilakukan untuk mengetahui adanya pengaruh perlakuan penambahan ektrak lidah buaya. pengamatan sifat fisik, kimia dilakukan uji analisis ragam ANOVA $5 \%$ dan $1 \%$. Apabila ditemukan pengaruh terhadap salah satu variabel maka dilanjutkan dengan uji beda nyata terkecil (BNT). Untuk uji organoleptik menggunakan uji Friedman pada 5\%.

Untuk parameter-parameter bersifat kualitatif yaitu kesukaan rasa, aroma dan tekstur dilakukan analisis ragam dengan metode Friedman dan jika terdapat perbedaan antar perlakuan dilanjutkan dengan uji Friedman termodifikasi untuk mengetahui perlakuan mana yang berbeda (Basker, 1988).

\section{Pengambilan Keputusan}

Pengambilan keputusan dilakukan untuk menentukan perlakuan mana yang terbaik dengan mempertimbangkan ke lima variable tersebut. Metode pengambilan keputusan yang dipergunakan adalah metode indeks efektifitas de Garmo, dkk (1984) yang dimodifikasi oleh Susrini (2003).

\section{HASIL DAN PEMBAHASAN}

\section{Kadar Air}

Kadar air sangat penting dalam menentukan daya awet dari bahan makanan karena mempengaruhi sifat fisik, kimia, perubahan, mikrobiologi dan perubahan enzimatis. Kandungan air dalam bahan makanan ikut menentukan penerimaan konsumen, kesegaran dan daya tahan bahan. (Winarno, 1997 dalam Kusdeni, 2012). Analisa kadar air kerupuk ekstrak lidah buaya diperlihatkan oleh gambar dibawah ini.

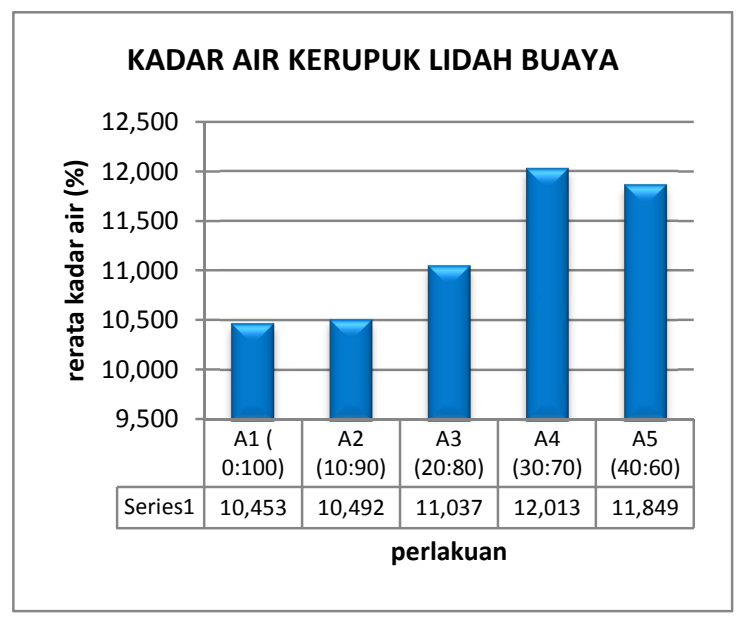

Gambar 1. Rata-rata kadar air (\%) kerupuk ekstrak lidah buaya

Berdasarkan analisa kadar air yang dilakukan pada kerupuk ekstrak lidah buaya, gambar 1 memperlihatkan rata-rata kadar air antara $10,453 \%$ sampai $12,013 \%$. Berdasarkan analisa sidik ragam, bahwa perlakuan penambahan ekstrak lidah buaya dan tepung menunjukkan pengaruh sangat nyata. Rata-rata nilai kadar air dari berbagai perlakuan ditunjukkan pada Tabel 1 .

Tabel 1 memperlihatkan bahwa perlakuan yang mempunyai kadar air terendah diperoleh dari perlakuan A1 (ekstrak lidah buaya 0 : tapioka 100) sebesar $10,453 \%$. Kadar air tertinggi diperoleh pada perlakuan A4 (ekstrak lidah buaya 30 : tapioka 70) yaitu sebesar $12,013 \%$ dan tidak berbeda nyata dengan perlakuan A5 (ekstrak lidah buaya 40 : tapioka 60) sebesar 11,849 
$\%$, tetapi berbeda nyata dengan perlakuan A1 (ekstrak lidah buaya 0 : tapioka 100) sebesar 10,453 \%, A2 (ekstrak lidah buaya 10g : tapioka 90) sebesar 10,492 \%, A3 (ekstrak lidah buaya 20 : tapioka 80) sebesar 11,037 $\%$. Semakin tinggi penambahan ekstrak lidah buaya, maka akan menghasilkan kerupuk dengan kadar air yang lebih tinggi. Hal ini disebabkan lidah buaya mengandung kadar air sekitar 95\%, sehingga akan mempengaruhi kerupuk yang dihasilkan.

Tabel 1. Rata-rata kadar air (\%) kerupuk ekstrak lidah buaya

\begin{tabular}{ccc}
\hline $\begin{array}{c}\text { Penambahan } \\
\text { Ekstrak Lidah } \\
\text { buaya dan Tepung }\end{array}$ & $\begin{array}{c}\text { Rerata } \\
(\%)\end{array}$ & Notasi \\
\hline A1 $(0: 100)$ & 10,453 & $\mathrm{a}$ \\
A2 $(10: 90)$ & 10,492 & $\mathrm{a}$ \\
A3 $(20: 80)$ & 11,037 & $\mathrm{a}$ \\
A5 $(40: 60)$ & 11,849 & $\mathrm{ab}$ \\
A4 $(30: 70)$ & 12,013 & $\mathrm{~b}$ \\
\hline BNT 5\% & \multicolumn{2}{c}{0,8512} \\
\hline
\end{tabular}

Keterangan: notasi yang berbeda nyata menunjukkan bahwa antar perlakuan yang berbeda nyata

Menurut Hartawan (2012) kandungan air pada lidah buaya mempunyai kadar air yang cukup tinggi, yaitu 95,510 \%. Ketentuan untuk standar maksimal kadar air pada kerupuk udang yang digunakan sebagai pembanding yang tercantum pada SNI 2714.1:1999 adalah sebesar 12\%.

\section{Antioksidan}

Antoksidan adalah senyawa yang mempunyai struktur molekul yang dapat memberikan elektronnya kepada molekul radikal bebas dan dapat memutus reaksi berantai dan radikal bebas. Antioksidan didefinisikan sebagai inhibitor yang bekerja menghambat oksidasi dengan cara bereaksi dengan radikal bebas reaktif membentuk radikal bebas tak reaktif yang relatif stabil. Akan tetapi jika dikaitkan dengan radikal bebas yang menyeb`abkan penyakit, antioksidan didefinisikan sebagai senyawasenyawa yang melindungi sel dari efek berbahaya radikal bebas oksigen reaktif
(Kumalaningsih, 2006 dalam Rosiani, 2011). Analisa antioksidan kerupuk ekstrak lidah buaya diperlihatkan oleh gambar dibawah ini.

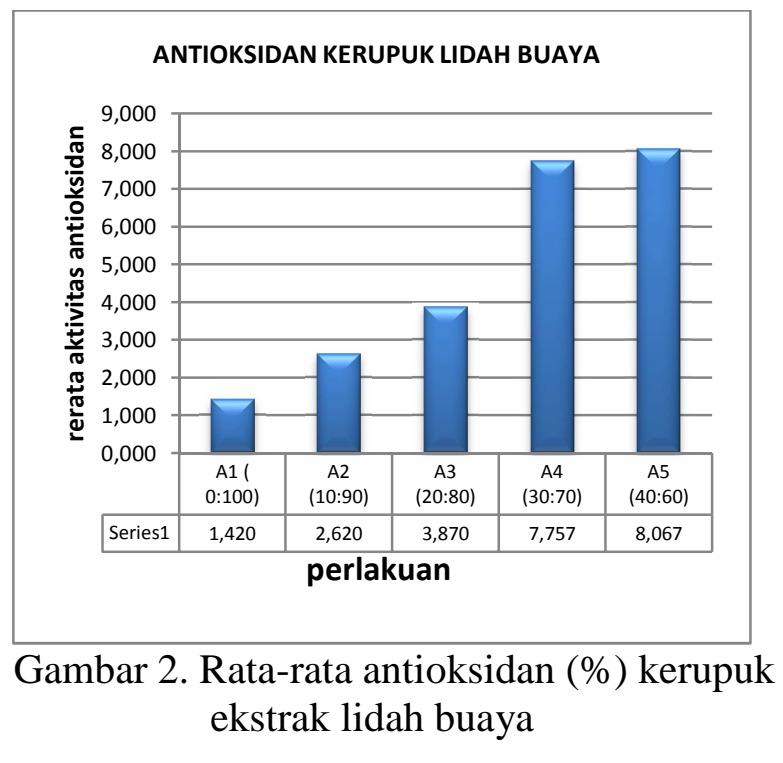

Berdasarkan analisa antioksidan yang dilakukan pada penambahan ekstrak lidah buaya, gambar 2 memperlihatkan rata-rata antioksidan antara 1,420 \% sampai 8,067\%. Berdasarkan analisa sidik ragam, bahwa perlakuan ekstrak lidah buaya dan tepung menunjukkan pengaruh sangat nyata. Ratarata nilai antioksidan dari berbagai perlakuan ditunjukkan pada Tabel 2.

Tabel 2. Rata-rata antioksidan (\%) kerupuk ekstrak lidah buaya

\begin{tabular}{crc}
\hline $\begin{array}{c}\text { Proporsi } \\
\text { Ekstrak Lidah buaya } \\
\text { dan Tepung }\end{array}$ & Rerata & Notasi \\
\hline A1 $(0: 100)$ & 1,420 & $\mathrm{a}$ \\
A2 $(10: 90)$ & 2,620 & $\mathrm{~b}$ \\
A3 $(20: 80)$ & 3,870 & $\mathrm{c}$ \\
A4 $(30: 70)$ & 7,757 & $\mathrm{~d}$ \\
A5 $(40: 60)$ & 8,067 & $\mathrm{e}$ \\
\hline BNT 5\% & \multicolumn{2}{c}{0,2590} \\
\hline
\end{tabular}

Keterangan : notasi yang berbeda nyata menunjukkan bahwa antar perlakuan yang berbeda nyata

Tabel 2 memperlihatkan bahwa perlakuan yang mempunyai antioksidan terendah diperoleh dari perlakuan A1 (ekstrak lidah buaya 0 : tapioka 100) sebesar 
1,420\%. Antioksidan tertinggi diperoleh pada perlakuan A5 (ekstrak lidah buaya 40 : tapioka 60) yaitu sebesar $8,067 \%$ dan berbeda nyata dengan perlakuan A1 (ekstrak lidah buaya 0 : tapioka 100), A2 (ekstrak lidah buaya 10 : tapioka 90), A3 (ekstrak lidah buaya 20 : tapioka 80), dan A4 (ekstrak lidah buaya 30 : tapioka 70), dengan masingmasing rata-rata $1,420 \% ; 2,620 \% ; 3,870 \%$ dan $7,757 \%$. Semakin tinggi penambahan ekstrak lidah buaya, maka akan menghasilkan kerupuk dengan antioksidan yang lebih tinggi. Menurut Hartawan (2012) dalam komponen gel lidah buaya terdapat antioksidan alami yang mengandung vitamin A sebesar 4,594 iu dan vitamin C sebesar $3,476 \mathrm{mg}$.

\section{Daya Kembang}

Daya kembang kerupuk dapat diukur dengan membandingkan luas kerupuk sebelum digoreng (mentah) dan luas kerupuk sesudah digoreng (matang) atau diukur garis tengah kerupuk sebelum digoreng dan sesudah digoreng. Cara mengukur daya kembang kerupuk adalah dengan menyiapkan alat ukur berupa penggaris. Kerupuk yang telah kering diukur luasnya dengan menggunakan penggaris. Selanjutnya mengukur kembali luas kerupuk setelah digoreng untuk mengetahui besarnya daya kembang kerupuk. Analisis daya kembang kerupuk ekstrak lidah buaya diperlihatkan oleh gambar dibawah ini.

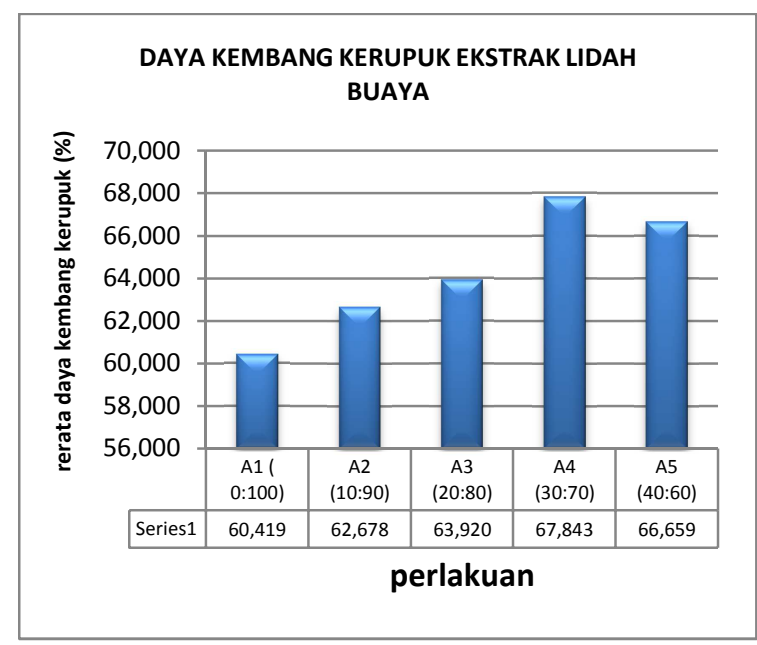

Gambar 3. Rata-rata daya kembang (\%) kerupuk ekstrak lidah buaya
Berdasarkan analisa daya kembang yang dilakukan pada penambahan ekstrak lidah buaya, Gambar 3. memperlihatkan ratarata daya kembang antara $60,419 \%$ sampai $67,843 \%$. Berdasarkan analisa sidik ragam, bahwa perlakuan penambahan ekstrak lidah buaya dan tepung menunjukkan pengaruh nyata. Rata-rata nilai daya kembang dari berbagai perlakuan ditunjukkan pada Tabel 3.

Tabel 3. Rata-rata daya kembang (\%) kerupuk ekstrak lidah buaya

\begin{tabular}{ccc}
\hline $\begin{array}{c}\text { Proporsi Ekstrak } \\
\text { Lidah Buaya } \\
\text { dan Tepung }\end{array}$ & Rerata & Notasi \\
\hline A1 $(0: 100)$ & 60,419 & $\mathrm{a}$ \\
A2 $(10: 90)$ & 62,678 & $\mathrm{a}$ \\
A3 $(20: 80)$ & 63,920 & $\mathrm{a}$ \\
A5 $(40: 60)$ & 66,659 & $\mathrm{~b}$ \\
A4 $(30: 70)$ & 67,843 & $\mathrm{~b}$ \\
\hline
\end{tabular}

\begin{tabular}{l|r} 
BNT $5 \%$ & 4,1664 \\
\hline
\end{tabular}

Keterangan: notasi yang berbeda nyata menunjukkan bahwa antar perlakuan yang berbeda nyata

Tabel 3. memperlihatkan perlakuan yang mempunyai daya kembang terendah diperoleh dari perlakuan A1 (ekstrak lidah buaya $0 \mathrm{~g}$ : ttapioka $100 \mathrm{~g}$ ) sebesar $60,419 \%$. Daya kembang tertinggi diperoleh pada perlakuan A4 (ekstrak lidah buaya $30 \mathrm{~g}$ : tapioka 70g) yaitu sebesar $67,843 \%$ dan tidak berbeda nyata dengan perlakuan A5 (ekstrak lidah buaya 40g : tapioka 60g) yaitu sebesar $66,659 \%$, tetapi berbeda nyata dengan perlakuan A1 (ekstrak lidah buaya $0 \%$ : tapioka $100 \%$ ) yaitu sebesar $60,419 \%$, A2 (ekstrak lidah buaya $10 \%$ : tapioka $90 \%$ ) yaitu sebesar 62,678\%, A3 (ekstrak lidah buaya $20 \mathrm{~g}$ : tapioka $80 \mathrm{~g}$ ) yaitu sebesar $63,920 \%$. Semakin tinggi penambahan ekstrak lidah buaya, maka akan menghasilkan kerupuk dengan daya kembang yang lebih tinggi. Hal ini didukung oleh Ernawati (2003) dalam Nifah (2015), berdasarkan besar kecilnya air yang diserap dalam granula pati, akan menentukan daya kembang pada saat pemasakan. Semakin tinggi air terikat, semakin besar pula daya kembangnya. 
Menurut Nurhayati (2008) dalam penelitiannya tentang sifat kimia kerupuk goreng yang diberi penambahan tepung daging sapi ini menjelaskan, meningkatnya kadar protein maka akan menurunkan kadar air. Menurunnya kadar air mengakibatkan penurunan daya kembang, karena semakin rendah kadar air mengakibatkan ketersediaan uap air untuk mengembangkan kerupuk juga ikut menurun. Menurut Muliawan (1991) dalam Mulyana dkk (2014), kadar air yang terikat dalam kerupuk sebelum digoreng sangat menentukan volume pengembangan kerupuk matang.

\section{Daya Serap Minyak}

Daya serap minyak kerupuk diukur jumlah minyak yang digunakan sebelum dan sesudah digoreng. Sedangkan menurut Kusumaningrum (2009) daya serap kerupuk diukur dengan membandingkan berat kerupuk mentah dan berat kerupuk setelah digoreng. Daya serap kerupuk merupakan kemampuan kerupuk di dalam menyerap minyak setelah digoreng. Analisis daya serap minyak kerupuk ekstrak lidah buaya diperlihatkan oleh gambar dibawah ini.

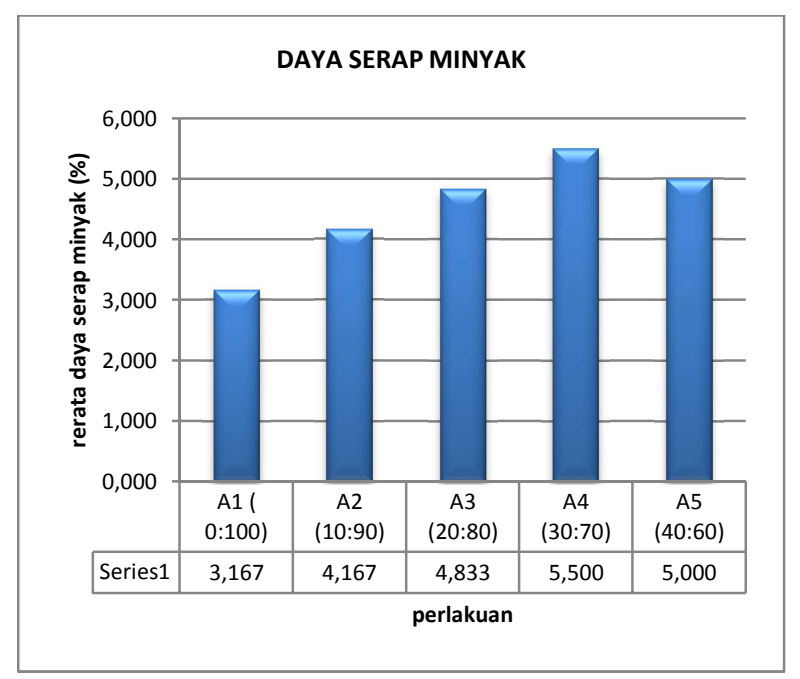

Gambar 4. Rata-rata daya serap minyak (\%) kerupuk ekstrak lidah buaya

Berdasarkan analisa daya serap minyak yang dilakukan pada proporsi ekstrak lidah buaya, Gambar 4 memperlihatkan rata-rata daya serap minyak antara 3,167 \% sampai $5,500 \%$. Berdasarkan analisa sidik ragam, bahwa perlakuan proporsi ekstrak lidah buaya dan tepung menunjukkan pengaruh nyata. Rata-rata nilai daya serap minyak dari berbagai perlakuan ditunjukkan pada Tbel 4 .

Tabel 4. Rata-rata daya serap minyak (\%) kerupuk ekstrak lidah buaya

\begin{tabular}{ccc}
\hline $\begin{array}{c}\text { Proporsi Ekstrak } \\
\text { Lidah buaya dan } \\
\text { Tapioka }\end{array}$ & Rerata & Notasi \\
\hline A1 $(0: 100)$ & 3,167 & $\mathrm{a}$ \\
A2 $(10: 90)$ & 4,167 & $\mathrm{a}$ \\
A3 $(20: 80)$ & 4,833 & $\mathrm{a}$ \\
A5 $(40: 60)$ & 5,000 & $\mathrm{~b}$ \\
A4 $(30: 70)$ & 5,500 & $\mathrm{~b}$ \\
\hline BNT 5\% & 1,1271 \\
\hline $\begin{array}{c}\text { Keterangan:notasi yang berbeda nyata menunjukkan } \\
\text { bahwa antar } \\
\text { nyata perlakuan yang berbeda }\end{array}$
\end{tabular}

Tabel 4 memperlihatkan bahwa perlakuan yang mempunyai daya serap minyak terendah diperoleh dari perlakuan A1 (ekstrak lidah buaya 0 : tapioka 100) sebesar $3,167 \%$. Daya serap minyak tertinggi diperoleh pada perlakuan A4 (ekstrak lidah buaya 30 : tapioka 70) yaitu sebesar 5,500\% dan tidak berbeda nyata dengan perlakuan A5 (ekstrak lidah buaya 40 : tapioka 60) yaitu $5,000 \%$, tetapi berbeda nyata dengan perlakuan A1 (ekstrak lidah buaya 0 : tapioka 100 ) ; A2 (ekstrak lidah buaya 10 : tapioka 90) ; A3 (ekstrak lidah buaya 20 : tapioka 80) ; dengan masing-masing rata-rata $3,167 \%$; $4,167 \% ; 4,833 \%$. Semakin tinggi penambahan ekstrak lidah buaya, maka akan menghasilkan kerupuk dengan daya serap minyak yang lebih tinggi. Menurut Kusumaningrum (2009) dalam penelitiannya menjelaskan daya serap yang tinggi menunjukkan terjadinya bagian yang matang dari kerupuk secara menyeluruh sehingga bagian tersebut menyerap banyak minyak. Jumlah minyak yang terkandung di dalam permukaan kerupuk menyebabkan kondisi kerupuk menjadi sedikit lebih berat dan kerupuk menjadi matang. Hal ini tentunya berbeda jika kerupuk memiliki daya serap minyak yang kecil, selain memiliki bagian kerupuk yang tidak matang dan yang lebih besar, juga akan menyebabkan kerupuk 
berada dalam kondisi yang tidak mengembang.

Bahan pangan yang digoreng menyebabkan kandungan air dalam bahan menguap yang ditandai dengan timbulnya gelembung selama proses penggorengan. Bersamaan dengan itu bahan pangan menyerap minyak dengan persentase penyerapan tergantung pada jenis bahan yang digoreng (Lawson, 1985 dalam Kusumaningrum, 2009).

\section{Analisis Sensori (Uji Organoleptik)}

Uji organoleptik atau uji indera atau uji sensor merupakan cara pengujian dengan menggunakan indera manusia sebagai alat utama untuk pengukuran daya penerimaan terhadap produk (Nifah, 2015).

\section{Rasa}

Hasil uji organoleptik menyajikan bahwa rata-rata ranking kesukaan panelis terhadap rasa dari perlakuan antara persentase penambahan ekstrak lidah buaya : tepung berkisar antara 3,90 (menyukai) sampai 4,40 (menyukai).

Semakin tinggi rata-rata nilai kesukaan panelis, maka tingkat kesukaan panelis terhadap rasa kerupuk ekstrak lidah buaya semakin besar. Rata-rata tingkat kesukaan panelis terhadap rasa kerupuk ekstrak lidah buaya ditunjukkan pada gambar 5 .

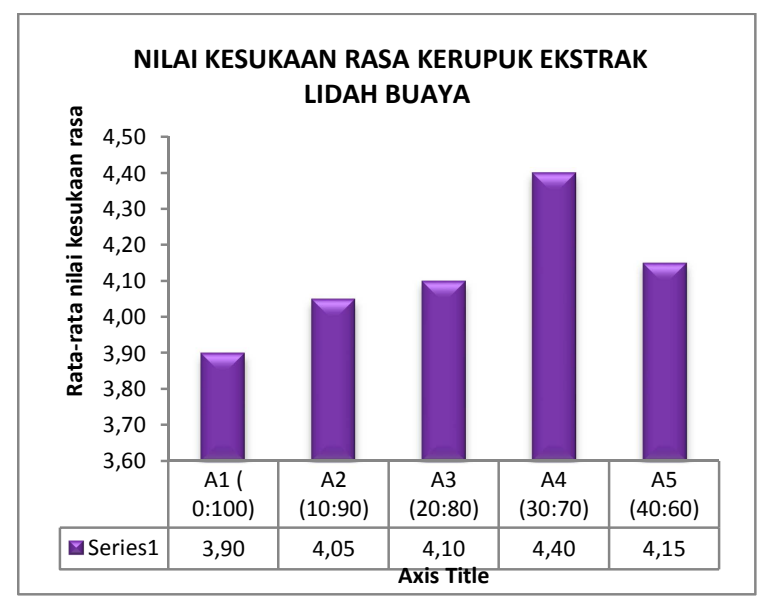

Gambar 5. Rata-rata organoleptik rasa kerupuk ekstrak lidah buaya

Gambar 5 memperlihatkan rata-rata nilai kesukaan panelis terhadap rasa kerupuk ekstrak lidah buaya mempunyai persentase terendah yaitu A1 (ekstrak lidah buaya 0 : tapioka 100) dengan nilai yaitu sebesar 3,90, sedangkan rata-rata nilai terhadap rasa mempunyai persentase tertinggi yaitu perlakuan A4 (ekstrak lidah buaya 30 : tapioka 70) dengan nilai yaitu sebesar 4,40 yang berarti menyukai.

Dari hasil pengamatan dapat disimpulkan bahwa semakin tinggi penambahan ekstrak lidah buaya maka rasa kerupuk ekstrak lidah buaya yang dihasilkan semakin disukai panelis. Hal ini dikarenakan kandungan antioksidan yang juga berfungsi sebagai pelindung bahan pangan terhadap deteriorisasi yang disebabkan oleh oksidasi seperti ketengikan, perubahan warna dan hilangnya nilai nutrisi. Namun kandungan getah atau lendir yang terdapat pada lidah buaya tidah meninggalkan rasa getah atau lendir dari produk.

\section{Aroma}

Hasil uji organoleptik menyajikan bahwa rata-rata ranking kesukaan panelis terhadap aroma dari perlakuan antara persentase kerupuk ekstrak lidah buaya berkisar antara 3,25 (netral) sampai 4,45 (menyukai).

Semakin tinggi rata-rata nilai kesukaan panelis, maka tingkat kesukaan panelis terhadap aroma kerupuk ekstrak lidah buaya semakin besar. Rata-rata tingkat kesukaan panelis terhadap rasa kerupuk ekstrak lidah buaya ditunjukkan pada gambar 6 .

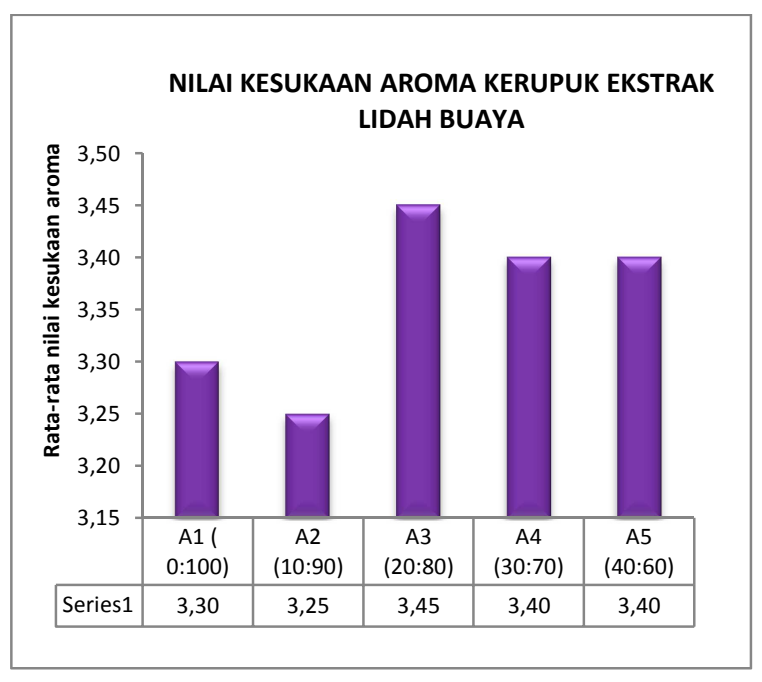


Gambar 6. Rata-rata organoleptik aroma kerupuk ekstrak lidah buaya

Gambar 6. memperlihatkan rata-rata nilai kesukaan panelis terhadap aroma kerupuk ekstrak lidah buaya mempunyai persentase terendah yaitu A2 (ekstrak lidah buaya $10 \mathrm{~g}$ : tapioka $90 \mathrm{~g}$ ) dengan nilai yaitu sebesar 3,25, sedangkan rata-rata nilai terhadap rasa mempunyai persentase tertinggi yaitu perlakuan A3 (ekstrak lidah buaya $20 \mathrm{~g}$ : tapioka $80 \mathrm{~g}$ ) dengan nilai yaitu sebesar 3,45 yang berarti netral.

Dari hasil pengamatan dapat disimpulkan bahwa semakin tinggi penambahan ekstrak lidah buaya tidak mempengaruhi aroma kerupuk ekstrak lidah buaya yang dihasilkan. Dari berbagai perlakuan, aroma kerupuk ekstrak lidah buaya yang didapat adalah dari bawang putih. Hal ini dikarenakan umbi bawang putih mengandung zat kimia yang berupa Allicin yang berperan memberi aroma pada bawang putih sekaligus berperan ganda membunuh bakteri gram positif maupun bakteri gram negatif karena mempunyai gugus asam amino para amino benzoat, sedangkan Scordinin berupa senyawa kompleks thioglosida yang berfungsi sebagai antioksidan dan pertumbuhan (Hernawan dan Setyawan, 2003).

\section{Tekstur (Kerenyahan)}

Hasil uji organoleptik menyajikan bahwa rata-rata ranking kesukaan panelis terhadap tekstur dari perlakuan antara persentase kerupuk ekstrak lidah buaya berkisar antara 3,60 (menyukai) sampai 3,90 (menyukai).

Semakin tinggi rata-rata nilai kesukaan panelis, maka tingkat kesukaan panelis terhadap tekstur kerupuk ekstrak lidah buaya semakin besar. Rata-rata tingkat kesukaan panelis terhadap rasa kerupuk ekstrak lidah buaya ditunjukkan pada gambar 7.

Gambar 7 memperlihatkan rata-rata nilai kesukaan panelis terhadap tekstur kerupuk ekstrak lidah buaya mempunyai persentase terendah yaitu A1(ekstrak lidah buaya $0 \mathrm{~g}$ : tapioka $100 \mathrm{~g}$ ) dengan nilai yaitu sebesar 3,60, sedangkan rata-rata nilai tertinggi terhadap tekstur mempunyai persentase tertinggi yaitu perlakuan A4 (ekstrak lidah buaya $30 \mathrm{~g}$ : tapioka $70 \mathrm{~g}$ ) dan A5 (ekstrak lidah buaya $40 \mathrm{~g}$ : tapioka $60 \mathrm{~g}$ ) dengan nilai yaitu sebesar 3,90 yang berarti netral.

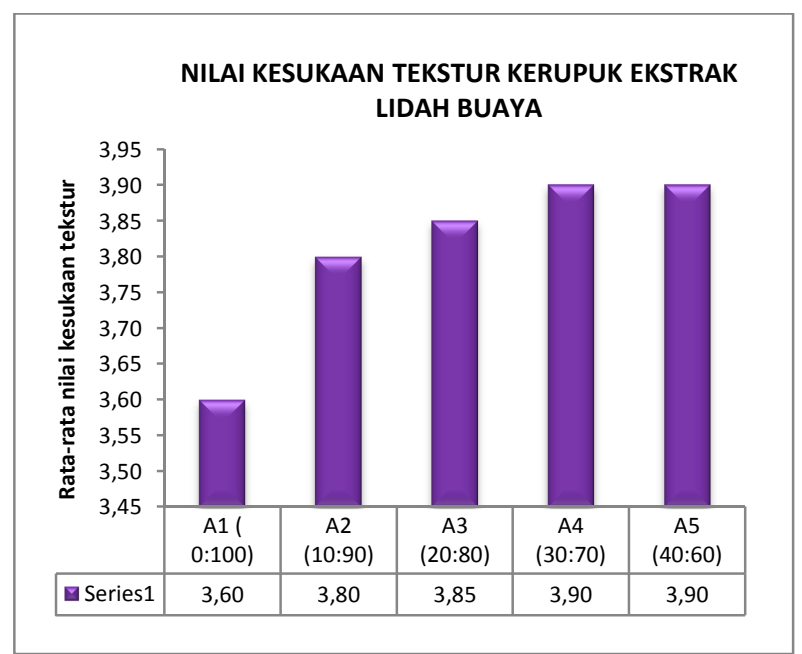

Gambar 7. Rata-rata Organoleptik Tekstur Kerupuk Ekstrak Lidah Buaya

Dari hasil pengamatan dapat
disimpulkan persentase penambahan ekstrak lidah buaya maka tekstur kerupuk ekstrak lidah buaya yang dihasilkan semakin disukai panelis. Hal ini dikarenakan dengan penambahan ekstrak lidah buaya yang semakin tinggi, akan menghasilkan daya kembang kerupuk yang semakin besar dan tingkat kerenyahan yang sangat renyah. Hal ini didudukung dengan penelitian Nifah (2015) yaitu, kerupuk yang menggunakan metode cair akan lebih mengembang dibandingkan dengan menggunakan metode padat, hal ini disebabkan karena metode cair lebih banyak mengandung air dan tingkat kerenyahan kerupuk sangat renyah.

\section{Uji Indeks Efektifitas}

Penentuan Perlakuan terbaik kerupuk ekstrak lidah buaya dilakukan dengan menggunakan metode indeks efektifitas (De Garmo, 1984) yang dimodifikasi oleh Susrini (2003). Metode ini dilakukan pada parameter kimiawi meliputi uji kadar air dan antioksidan, uji fisik meliputi daya kembang 
dan daya serap minyak, serta uji organoleptik meliputi rasa, aroma dan tekstur. Bobot parameter mulai dari yang tertinggi sampai yang terendah adalah rasa rasa 0,209 ; aroma 0,161 ; daya serap minyak 0,159 ; tekstur 0,141 ; antioksidan 0,139 ; daya kembang 0,125; kadar air 0,066. perhitungan pembobotan kriteria ini dapat dilihat pada lampiran 10. Bobot parameter disajikan pada gambar 8 .

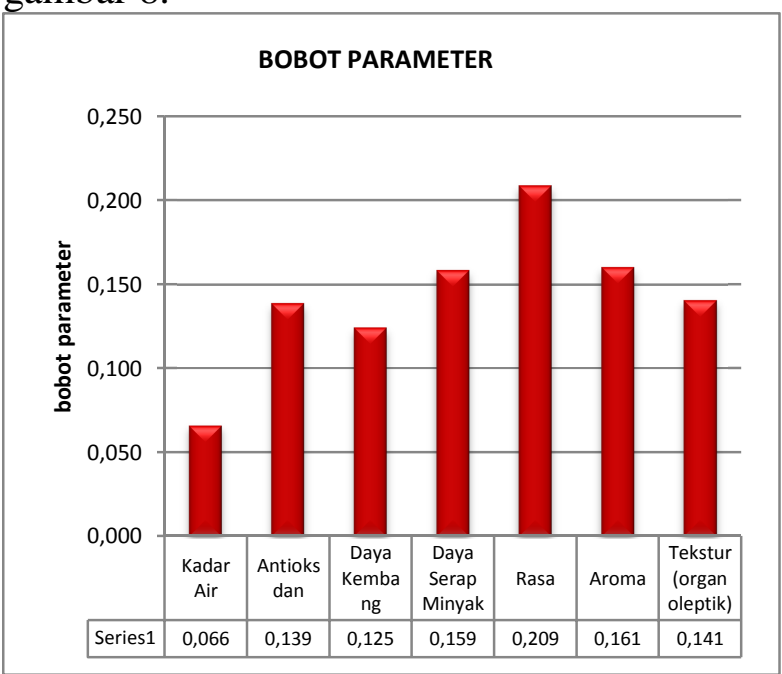

Gambar 8. Bobot parameter uji indeks efektifitas

Setelah diketahui bobot tiap kriteria selanjutnya dilakukan perhitungan nilai efektif untuk mendapat nilai tiap perlakuan yang terbaik. Berdasarkan gambar 10, didapatkan perhitungan dengan nilai produk tertinggi adalah A4 (proporsi ekstrak lidah buaya $30 \mathrm{~g}$ : tepung tapioka $70 \mathrm{~g}$ ) dengan karakteristik sebagai berikut: rata-rata kadar air $12,013 \%$; antioksidan $7,757 \%$; daya kembang $67,843 \%$; daya serap minyak 5,500 $\%$; serta rata-rata tingkat kesukaan panelis terhadap rasa 4,40; aroma 3,40; dan tekstur 3,90 .

\section{KESIMPULAN DAN SARAN}

\section{Kesimpulan}

1. Berdasarkan hasil penelitian didapatkan bahwa antara proporsi ekstrak lidah buaya dan tepung terhadap berpengaruh nyata terhadap kadar air, antioksidan, daya kembang, daya serap minyak serta organoletik rasa, aroma, tekstur (kerenyahan).
2. Berdasarkan hasil penelitian didapatkan perlakuan terbaik yaitu penambahan ekstrak lidah buaya 30 : tapioka 70 , dengan karakteristik kadar air 12,013\%; antioksidan 7,757 \%; daya kembang $67,843 \%$; daya serap minyak $5,500 \%$; serta rata-rata tingkat kesukaan panelis terhadap rasa 4,40 (menyukai); aroma 3,40 (netral); dan tekstur 3,90 (menyukai).

\section{Saran}

1. Perlu dilakukan penelitian lanjutan tentang metode pembuatan kerupuk yaitu metode padat dibandingkan dengan metode cair untuk menghasilkan kerupuk yang mempunyai mutu yang baik.

2. Perlunya dilakukan penelitian lanjutan terutama tentang masa simpan produk dan cara pengemasan yang baik sehingga didapatkan produk kerupuk yang mempunyai mutu yang baik selama penyimpanan.

\section{DAFTAR PUSTAKA}

De Garmo, E. D, G. Sullivan and J. R. Canada. 1984. Engineering economis. Mc. Millan Publishing Company. New York.

Fitrina. F, Ali. A, dan Fitriani.S. 2012. The ratio of aloe vera and seaweed on the quality of jelly candy. Jurnal Ilmu Pangan 13 (1): 14-21

Harper L.J, Brady J. Deaton, Judy A. Driskel. 1986. Pangan, gizi dan pertanian. Penerjemah Suhardjo. Penerbit Universitas Indonesia (UI-Press) Jakarta.

Hartawan.E.Y. 2012. Sejuta khasiat lidah buaya. Pustaka Diantara. Perpustakaan Nasional.

Hernawan. U.E dan Setyawan. A.D, 2003. Senyawa organosulfur bawang putih (Allium Sativum L.). Biologi FMIPA UNS Surakarta. Surakarta.

Kusdeni, E. 2012. Pengaruh persentase dan lama perendaman dalam kapur sirih $(\mathrm{CaOH} 2)$ terhadap kualitas keripik talas 
ketan (Colocassia esculanta). Skripsi. Universits Yudharta Pasuruan. Pasuruan.

Kusumaningrum, I. 2009. Analisa faktor daya kembang dan daya serap kerupuk rumput laut pada variasi proporsi rumput laut (Eucheuma cottonii). Studi Teknologi Hasil Perikanan Jurusan Budidaya Perikanan FPIK Universitas Mulawarman.

Mulyana, S, W.H, Purwantiningrum, I. 2014. Pengaruh proporsi (tepung tempe semangit : tepung tapioka) dan penambahan air terhadap karakteristik kerupuk tempe semangit. Universitas Brawijaya Malang. Malang. Jurnal Pangan Dan Agroindustri 2 (4) : 113120.

Nifah, K. 2015. Pengaruh proporsi tepung (tapioka-tempe) dan metode pembuatan adonan terhadap sifat organoleptik dan fisik kerupuk tempe. Jurnal Pangan 4: (3).
Nurhayati. A.2008. Sifat kimia kerupuk goreng yang diberi penambahan tepung daging sapi dan perubahan bilangan TBA selama penyimpanan. Skripsi. Teknologi Hasil Ternak. Institut Pertanian bogor. Bogor.

Purwaningsih, Dyah. 2008. Prospek dan peluang usaha pengolahan produk (Aloe vera L.) Jurdik Kimia, FMIPA UNY

Rosiani, Nurwachidah. 2011. Pembuatan kerupuk dengan fortifikasi daging lidah buaya (Aloe vera). Tugas Akhir/skripsi. Universitas Sebelas Maret.

Santoso, T. S, 2008. Analisis finansial usaha kerupuk (studi kasus: kerupuk suka asih (SKS) di Pondok Labu, Jakarta Selatan). [Skripsi] Universitas Islam Negeri Syarif Hidayatullah. Jakarta.

Susrini, 2003. Indeks efektivitas. Fakultas Peternakan Universitas Brawijaya. Malang 